\title{
Husbandry Practices and Utilization of Camel Products in Borana Zone of Southern Oromia, Ethiopia
}

\section{Dejene Takele Gebissa}

Oromia Agricultural Research Institute, Yabello Pastoral and Dryland Agriculture Research Center, Dairy Research Team, Yabello, Ethiopia

\section{Email address:}

dejugindo@hotmail.com

\section{To cite this article:}

Dejene Takele Gebissa. Husbandry Practices and Utilization of Camel Products in Borana Zone of Southern Oromia, Ethiopia. Science Research. Vol. 3, No. 4, 2015, pp. 191-197. doi: 10.11648/j.sr.20150304.16

\begin{abstract}
This survey was conducted in Borana zone to assess camel husbandry and product utilization practices, and identify major constraints of camel production. The result showed that camel was ranked the first economically important livestock species followed by goats and cattle, consecutively. Per producer holding of female of 1-3 year, heifer of 3-5 year, matured female of greater than 5 year, male of 5 year, male of less than 5 year and breeding bull greater than 5 year camel was $4.17,2.50,3.83,1.83,0.50$ and 0.50 , respectively. Selection of breeding bull and female camel and uncontrolled mating was common practices. Lactation length was 13.38 months while daily milking frequencies were 3.24 and 2.57 during wet and dry season, respectively. Daily milk yield per camel was 8.4 and 4.75 liters for wet and dry seasons, respectively. A liter of camel milk cost 2.30 and 4 birr during wet and dry season, respectively. Disease, poisonous plants, and low extension and health services were the main problems of camel production. Boosting the capacity of the community on improved husbandry practices and product utilization, and developing coordinated efforts for camel diseases control and prevention schemes should be an assignments of all stakeholders.
\end{abstract}

Keywords: Camel, Husbandry Practices, Meat, Milk Utilization, Borana Zone, Ethiopia

\section{Introduction}

The camel (Camillus dromedaries) is an important livestock species uniquely adapted to arid and semi-arid environments. It is most numerous in the arid areas of Africa, particularly in the arid lowlands of Eastern Africa namely, Somalia, Sudan, Ethiopia, Kenya and Djibouti. With increasing human population pressure, change in ecology and declining per capita production of food in Africa, there is an urgent need to develop previously marginal resources, such as the semi-arid and arid rangelands, and to optimize their utilization through appropriate livestock production systems of which camel production is certainly the most suitable one (Schwartz, 1992).

There are around 1 million camels in Ethiopia, and16.16\% of which is reported in Borana zone (Workneh, 2002). Despite its ecological and economic importance and significant role in the life of pastoral community, until recently the animals were neglected by researchers and development planners in Ethiopia (Yesihak and Bekele, 2003). Little is known about production and health problems of the camel compared to other livestock. However, documenting husbandry and breeding management practices, describing the basic production and reproduction characteristics of the camel, and identifying the prevailing opportunities and constraints have substantial importance to design sustainable camel improvement strategies. This study was, therefore, initiated to analyze the husbandry practices and utilization of camel products as well as to identify the main opportunities and constraints for low productivity of pastoral camel.

\section{Materials and Methods}

\subsection{Study Area}

The survey was conducted in the range land of Borana Zone of the Oromia Regional State from 2010 to 2012. Borana pastoralists are traditionally known for the Ethiopian Borana cattle (Desta S and Coppock DL, 2002). However, due to the recurrent drought and the reluctant feed shortage, camel and small ruminants are becoming an important 
livestock species in the area.

\subsection{Sampling and Data Collection}

Three districts namely Yabello, Moyale and Mio were selected based on their potential for camel production and accessibility. A total of 6 kebeles (two from each district) were randomly selected where the interview was administered to the selected herder of camel. Using a semistructured the survey was carried out by trained enumerators through a single visit formal survey following the procedures of ILCA (1990) questionnaire. Information on camel herd structure, reproductive management, camel feed and feeding practices, health care service, milk and meat utilization practices, and marketing practices of the animal were assessed.

\subsection{Statistical Analysis}

Data were analyzed using the Statistical Packages for Social Sciences (SPSS of version 17). Ranking the livestock species based on their level of importance was carried out using the formula to compute the index as employed by Musa et al. (2006).The desired interpretation for both quantitative qualitative parameters was done descriptively.

\section{Results and Discussion}

\subsection{Demographic and Socio-economic Characteristic of the Households}

As the general demographic characteristics of the households are presented in Table 1, about $72.8 \%, 16.3 \%$ and $10.8 \%$ of the respondents belonged to the Borana, Gabra and Gari ethnic groups, respectively.

Table 1. Demographic Characteristics of the Respondents of the Study Areas.

\begin{tabular}{ll}
\hline Descriptor & Percent \\
\hline Ethnic group & \\
Borana & 72.8 \\
Gabra & 16.3 \\
Gari & 10.8 \\
Religion & \\
Muslim & 59.8 \\
Wakefata & 39.1 \\
Christian & 1.1 \\
\hline
\end{tabular}

About $59.8 \%, 39.1 \%$ and $1.1 \%$ of them were followers of Muslim, Wakefata and Christian religion, respectively. All of the households were headed by men. Less than half (46\%) of the respondents were illiterate.

Whereas 23.9 and $26.1 \%$ were attended primarily and religion school, respectively

Like any other pastoral system of the world, the study population was mainly engaged in livestock production where few of them were also practicing crop production (agro-pastoralist). According to the participants of the study area some of the predominant livestock species comprised of cattle, camel, goats, sheep, chicken and donkey. The respondents were ranking their livestock species based up on their importance in carrying out their way of life as presented in Table 2. As per the response of the participants, camel was ranked first followed by goats and cattle for those engaged in camel production. The better position of camel as compared to other species could be associated with the better adaptation of camel for recurrent drought and ecological changes which favor camel to be in increasing trend than other livestock species.

Table 2. Ranked Livestock Species Based on their Importance (\%).

\begin{tabular}{lllll}
\hline Livestock species & Rank1 & Rank 2 & Rank3 & Index \\
\hline Cattle & 17.40 & 1.10 & 9.80 & 0.11 \\
Camel & 82.60 & 57.60 & 9.80 & 0.64 \\
Goat & 0.00 & 23.90 & 54.30 & 0.18 \\
Sheep & 0.00 & 16.30 & 1.10 & 0.06 \\
Chicken & 0.00 & 0.00 & 2.20 & 0.00 \\
Donkey & 0.00 & 0.00 & 4.30 & 0.01 \\
\hline
\end{tabular}

Index $=$ sum of [ 3 for rank $1+2$ for rank $2+1$ for rank 3 ] for particular species of livestock divided by sum of [ 3 for rank $1+2$ for rank $2+1$ for rank 3] for all species.

\subsection{Herd Structure, Breeding Management Practice and Reproductive Characteristic}

This study revealed that camel rearing started at an average of before 25.93years ago. The period of engagement in camel production was varying among the ethnic groups. The Borana and Gabra have started camel rearing 21.82 and 41.25 years back, respectively. The reasons behind recently involvement of the Borana community as compared to the Gabra are probably an emerging strategy of the community is to diversify their way of life as copping mechanism for recurrent drought. Despite the cultural taboos against the consumption of camel milk and meat by the Borana, the better milk, meat and market values inspired them to share the experience of Gabra ethnic group.

The pastoralists have been rearing different camel heard structure whose proportion varies from one category to the other as depicted in Figure 1 below. There were more female than male camels for all age categories. In pastoral herds of Ethiopia, the proportions of breeding females have been reported to be 50\% (Megersaet al., 2008), and 51\% (Getahun $\&$ Kassa, 2002). Larger proportions of females in herds of the study areas indicate a strong desire of herdsmen to maximize herd size and the importance of milk production in pastoral areas. Keeping only the male for breeding purpose, the pastoralists have been reducing the population of male camel through selling.

There was the selection practice for breeding bull and female in the study area. Bull was selected at an average age of 4.85years based on the qualities of bull's dam and sire and himself (according to the $90.2 \%$ of the respondents). Female was selected at average age of 3.5 years based on pedigree information, udder size, and temperament and body condition of the animal according to the $31.5 \%, 20.7 \%$ and $20.7 \%$ of the respondents. The majority of the respondents $(73.9 \%)$ kept their own breeding bull born in the herds. About 19.6\% and $3.3 \%$ of camel keepers share bulls from their neighbors' 
and bulls purchased from market, respectively. The majority of the respondents $(90 \%)$ reported that in case they owned more than one breeding bulls, it was only one bull that was active enough to give mating service. This finding indicated that camel bulls have the nature of dominating each other and except the strong and dominant bull and hence others are forced to be remain passive until the strong one is get older or culled by the owners. It was found that all the respondents practice inbreeding allowing mating of closely related individuals (bulls with own mothers, bull to sisters and daughters). For about $58.7 \%$ of the sampled respondents, camel mating took place both indoor and outdoor. However, about $38 \%$ and $1.1 \%$ of the respondents reported mating to take place indoor and outdoor, respectively. The main mating season was during the short rainy season (Hagaya) which extends from September to November. This is in agreement with the findings of Yagil and Etzion (1980) that camels are seasonal breeders, and mating during the rainy and cold season.

\title{
Different Categories of Camel Holding per Household of the
}

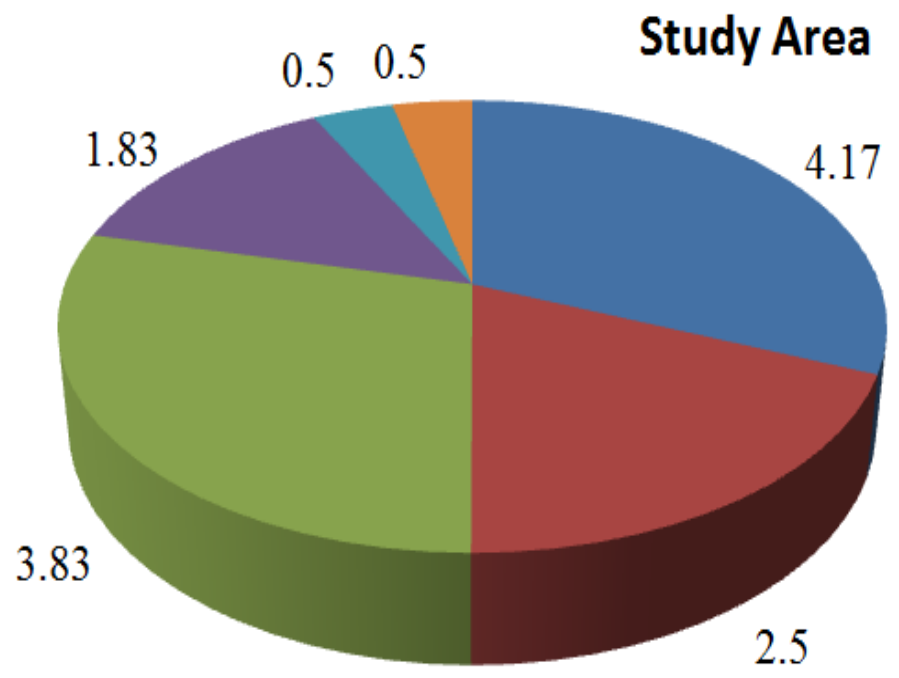

\author{
- Female camel 1-3 year \\ - Heifer 3-5 year \\ Matured female greater than 5 year \\ Male of 5 year \\ - Male less than 5 year \\ Breeding bull greater than 5 year
}

Figure 1. Camel Herd Structure Reared by Household of Borana Zone.

Castration was practiced by $64.10 \%$ of the producers mainly to improve fattening potential and for better market values. Traditional castration method and castration at short rainy season (September-November) when feed resource is available was common practices.

Table 3. Camel Reproductive Characteristics of Borana Zone.

\begin{tabular}{|c|c|c|c|c|}
\hline Traits & $\mathbf{N}$ & Minimum & Maximum & Mean \pm SD \\
\hline Age at first mating for breeding bull (yrs) & 90 & 4 & 7 & $5.56 \pm 0.74$ \\
\hline Age at first mating for breeding female (yrs) & 88 & 4 & 6 & $4.56 \pm 0.60$ \\
\hline Age at first calving (yrs) & 91 & 1 & 12 & $4.99 \pm 1.04$ \\
\hline Life time calf crop (No) & 91 & 7 & 22 & $11.93 \pm 2.68$ \\
\hline Service period for breeding bull(yrs) & 91 & 6 & 25 & $14.55 \pm 3.85$ \\
\hline
\end{tabular}

$\mathrm{N}$ refers to number of respondents; SD refers to standard deviation; yrs refer to years and No refers to number of calf

The depicted results in Table 3 indicates the prolonged age at first calving and longer calving intervals which can partly explain the low calf production. The average calving interval (17.73 months) of camel of the study area is nearly in line with the report of Schwartz and Walsh (1992) who reported 15 to 18 months. Environmental factors like nutritional and other management practices are determinant factors in affecting the performance of reproductive traits others than the genotypic influence. Therefore the above mentioned figures at the respective traits are good indicative to revisit how the overall management practices were going on at farm level.

\subsection{Camel Feeding and Watering Practice}

The locally available common camel browses especially during the summer season were Acacia brevispica (Hameressa), Grewiatembensis (Dheka), Hamessa, Tatessa, and others. Feed shortage was reported as a problem particularly in the dry season $(80.4 \%)$, but water shortage was a rare problem in camel production $(2.2 \%)$. On average camels travel 0.03 and $3.96 \mathrm{~km}$ in searching feed during the dry and wet season, respectively. The grazing hours were 9.95 and 12 hrs for the wet and dry seasons, respectively. According to the majority of respondents (98.9\%) feed shortage was compacted with supplementation of camel with locally available feed resources like leaves of some browses 
and pods of some acacia species. These supplements were provided mainly for calves, weak and sick animals. Minerals supplementation was provided for almost all categories of camels. Locally available mineral salts were Boke $(90.2 \%)$, Dillo (96.7\%), Magado (92.4\%) and Chuluke (3.3\%) where the Dillo type was considered as the most important type for camel feeding. Predominantly mineral supplementation was carried out at home $(96.7 \%)$ with the intervals of $14.8 \pm 10.92$, $17.8+9.31,17.8 \pm 9.31,17.9 \pm 9.35$ and $17.7 \pm 9.29$ days for calves, young, adults, lactating and castrated camels, respectively.

Regardless of camel's capacity to conserve water, it is inhabitable for the camel to alive without gaining the minimum requirement at a given interval. The sources of water for camels during the main dry season of an area were deep wells $(95.7 \%)$, bore holes $(22.8 \%)$ and ponds $(71.7 \%)$. About $79.3 \%$ the respondents confirmed that the main source of water for the wet season was rain water. They watered their camels with the interval of $6.4 \pm 3.02,6.1 \pm 2.09,6.1 \pm 2.09$ and $6.1 \pm 2.10$ days for calves, young, adult and lactating camels, respectively. Adult animals were travelling on average about $7.75 \mathrm{~km}$ for the search of water where as calves were often watered at home during the dry season.

\subsection{Camel Diseases and Health Management Practices in Borana Zone}

The major camel diseases identified include: coughing (Dhuguda), respiratory complex disease (Furi), Butal, nervousness (Sinbirk) and trypanosomosis (Dhukan). Widespread diseases, poor veterinary service and lack of attention by the government are the major constraint to camel production in the area. There is nobody possessing more competence for camel health care than the herders. They have produced camels since the date of starting by their own efforts without much assistance. The majority of the identified diseases were affecting all age and sex groups. The majority $(81.32 \%)$ of camel keepers did not have access for veterinary service. Vaccination was not rendered for the animals. Spraying against external parasites was applied by $5 \%$ of the households and traditional treatment was used by $45 \%$ the sampled camel keepers. Deworming against internal parasites was done by none of the respondents. $80.8 \%$ of the respondents indicated that Grewia bicolor (Haroressa), Garbicha, Gadalle and Daalacha were identified as poisoning plans. The plants were still the threats for rearing camel so that special cares has been given to the camel not to grass or brose the identified plant species.

\subsection{Camel Housing Practices in Borana Zone}

Almost all the camel breeders kept their animals in kraal made up of thorny bushes to protect the animals from some predator. Except calves where they kept in calve pens, all categories of camels housed together. Kraal was cleaned every of $14.3+15.22$ days interval. But during the wet season, only $32.6 \%$ of the respondents were clean the Kraal every $2.6 \pm 7.28$ days. It was noted that kraal was changed almost monthly $(31.8 \pm 21.12)$ to reduce muddiness which might harbor flies.

\subsection{Camel and Camel Product Utilization}

This particular survey identified that camels were kept for different purposes (Table 4). Likely the study of Amin (1984) reported that there are five main areas where camels can contribute under the Borana setting: milk and meat production, transportation service, wealth status indication and source of income generation.

High milk and meat production (98.9\% and 96.7\%) was reported to be the primary purpose of camel production in the area followed by income generation (92.4\%), and transportation $(83.7 \%)$. However, it was the male camel that was kept as back animals to transport goods to the market and to the mobility sites $(83.7 \%)$, water transportation using male camels.

Table 4. Purposes of Keeping Camel in Borana Zone.

\begin{tabular}{lll}
\hline \multirow{2}{*}{ Purpose } & \multicolumn{2}{c}{ Animal category } \\
\cline { 2 - 3 } & Male camel & Female camel \\
\hline Source of meat & 96.7 & 76.1 \\
Milk production & 0.0 & 98.9 \\
Breeding & 58.7 & 55.4 \\
Source of income & 92.4 & 7.5 \\
Blood & 9.8 & 5.4 \\
Hide & 7.6 & 5.4 \\
Saving & 78.3 & 79.3 \\
Wealth indicator (prestige) & 37 & 62.0 \\
Transportation & 83.7 & 15.4 \\
\hline
\end{tabular}

Camel as transporting human was rarely used by the producers. Camel as back animals was reported in wide ranges of communities (Schwartz and Walsh, 1992; Wilson, 1998; Melaku and Feseha, 2001; Razaet al., 2004). Like in other parts of our country there was the practice of rarely utilizing camel blood and hide in the study site.

\subsection{Camel Marketing and Determination its Price in Borana Zone}

As source of income over $92.4 \%$ and $7.5 \%$ of the respondents were selling male and female camel, respectively. About $65 \%$ of the respondents reported that they were mobilized by the agents of the camel traders, who were resided within the community, on the categories of the animal/camel the market currently needed. But the other, $35 \%$, of the respondents reported that they were supplying camel to the market, without prior marketing information, just to satisfy their capital need or to cull the older or other camel not required for reproduction. There was no separate market place and day for marketing camel other than the one employed for other species of livestock. Price determination was solely done by the pastoralist themselves without any other person interference despite some bargaining activities by the purchasers up on the price mentioned by the suppliers. Hence, the average price of the live camel according to the sellers was summarized in the Table 5 where the words in the parenthesis are the common name given to each categories of 
camel. The result indicated that the average price of various category of camel is by far better than other livestock species. This variation could be the higher productivity of camel for both milk and meat production in dry land area, and the currently emerging practice of exporting live camel over the sea.

The price of breeding female was relatively higher than other category which is an indication of higher emphasis given to camel rearing by domestic residents. The average market price for breeding bull (18500.40 birr) and castrated camel (1578.20 birr) was more than two fold of the market price estimation report of Borana Zone Pastoral Development Office (2010) probably because of the dramatically uprising market demand over the sea.

Table 5. Price of camel of different age and sex categories in Borana Zone (birr*).

\begin{tabular}{llll}
\hline Animal category & Minimum & Maximum & Mean \pm SD \\
\hline Castrate & 7000.00 & 17000.00 & $1578.20 \pm 933.76$ \\
Breeding male & 11200.00 & 19000.00 & $18500.40 \pm 533.50$ \\
Breeding female & 14000.00 & 22500.00 & $20065.60 \pm 640.80$ \\
Young male (Jibota) & 3700.00 & 7500.00 & $6500.00 \pm 622.25$ \\
Young female (Orge) & 4500.00 & 13000.00 & $7700.80 \pm 489.75$ \\
Lactating (Hawicha) & 5200.00 & 7000.00 & $12000.75 \pm 530.80$ \\
Older (Dulacha) & 1200.00 & 3400.00 & $3800.45 \pm 763.65$ \\
Culled male & 1550.00 & 4700.00 & $3208.90 \pm 3783.70$ \\
Culled female & 2500.00 & 5500.00 & $3413.00 \pm 1185.60$ \\
\hline
\end{tabular}

* refers to 16.5877 Ethiopian Birr $=1 \mathrm{US} \$$ at the time of administering the survey

In most cases, the older and culled camels were used by local slaughter that was why the great deterioration of their market price was observed in the study area since local consumption of camel meat was limited to few ethnic group and religion followers. Beyond the physical selling, saving live camel as an asset at the time of prolonged drought was largely accustomed. This was done as the pastoralist was well recognized the by far relative capability of camel to tolerate recurrent drought while compared to other livestock species.

Despite the higher opportunity that is expected to be exploited from camel marketing, the unbalanced off take coupled with the naturally low reproductive rates would significantly affect the genetic resource base of the population.

\subsection{Camel Milk Production and Utilization in Borana Zone}

The majority of respondents indicated that the lactation length of camels was 13.38 months on average. This finding is in agreement with the previous finding of Tezera (1998) who reported 13 to 15 months. However, it is shorter than 15 to 18 months for Afar and higher than 6 months for Kereyu camels as per the report of Schwartz and Walsh (1992) and Alemayehu (2001), respectively. This variation might be emanated from breed type, agro-ecological differences and management practices. This finding is in agreement with Ahmed (2002) who stated that the lactation length varies depending on the management decision of the owners.
Elongation of lactation length prevents pregnancy and then maintains milk production for family consumption as well as to safeguard the calf. The frequency of milking, yield and price of camel milk vary from season to season (Table 6). It was observed that there was a significant difference in milk production and price $(\mathrm{P}<0.05)$ across season. The milk yield of wet season was decreased by half during the dry season probably due to the variation in feed condition over the seasons.

Table 6. Camel Milking Frequency, Milk Yield and Milk Price of Borana Zone.

\begin{tabular}{lll}
\hline \multirow{2}{*}{ Variables } & \multicolumn{2}{l}{ Season of the Year } \\
\cline { 2 - 3 } & Wet Season & Dry Season \\
\hline Milking frequency/day & 3.24 & 2.57 \\
Milk yield (liter/day) & 8.40 & 4.75 \\
Milk price (birr*/liter) & 2.30 & 4.00 \\
\hline
\end{tabular}

* refers to 16.5877 Ethiopian Birr $=1$ US\$ at the time administering the survey

While the price was doubled in the long dry season since there could be low supply and high demand for milk during this period. This finding is in agreement with Zeleke (1998) who stated the average price was higher during dry than wet season. Similar milking frequency of the current study was observed in the report of Getahun T and Kassa B (2002) who indicated 3.23 and 2.29 times per day for wet and dry seasons, respectively. Camel milk is the stable diet for the Gabra ethnic group, but a few Borana tribes rarely consume camel milk due to cultural taboos against consumption of camel. Milk was meant both for home consumption and selling. Camel milk is not processed by the higher proportion $(96.7 \%)$ of respondents. This could be due to the hardening nature of camel milk to be processed in to its byproducts.

\subsection{Camel Meat Production and Utilization of Borana Zone}

According to the $59.8 \%$ of the respondents, camel slaughtering was practiced at large for the last one year. However, $30.4 \%$ of the respondents indicated that they did not slaughter during the last one year because of the cultural taboos against the consumption of camel meat. An average of $1.02 \pm 0.52 \mathrm{camel}$ was slaughtered per year per the household. There was no variation as regard to the type of animals category meant for slaughtering purpose. Unlike other parts of Ethiopia, there was no preference of sex of a particular animal for slaughtering purpose. Mainly camel was slaughtered for socio-cultural purposes like festivals, wedding, mourning, religion and hosting guests. This finding concurred with the observation of Mohamed (1993), Ahmed (2002) and Farah et al. (2004), who stated that camel meat consumption for pastoralists is occasional. The majority of the respondents (76.1 to $96.7 \%)$ believed that camel production was preferred for its higher meat production potential. 


\section{Conclusions and Recommendations}

This survey indicated that camel is becoming the most important livestock species for the pastoralists of Borana zone irrespective of the high level of inbreeding practice that inhabitable affect the overall productivity. Therefore, there is an urgent need to introduce controlled breeding system at least to minimize its effects. Information on nutritional values camel feed is sparse recognized. Hence, the identified local feed resources should be subjected to chemical analysis. Camel production is a short aged activity to the Borana ethnic group resultant with less experience in camel husbandry and management practices. Thus, there is a need to boost their capacity through training on improved camel managing practices and develop appropriate camel diseases control and prevention schemes so as to enhance productivity of the sector. Asset diversification is one of the viable options to reduce risks associated with environmental changes and recurrent drought for pastoralists inhabiting arid and semiarid areas. Therefore, there is a need to create awareness on camel product utilization among the Borana community.

\section{Acknowledgement}

I would like to acknowledge Oromia Agricultural Research Institute for their invaluable financial support for the success of this study. Grateful thanks also remained to the staff members of Yabello Pastoral and Dry land Agriculture Research Center, namely Mr. Zewdu Edea, Mr. Tamiru Amanu and Mr. Tamirat Tesema, for their unreserved collaboration during data collection and honest and constructive comments during the progress of the survey.

\section{References}

[1] Ahmed M (2002). Study on practices and problems of camel production in Afder zone of Somali national regional state, Ethiopia. An MSc Thesis Presented to the School of Graduate Studies of Alemaya University. pp.148.

[2] Alemayehu G (2001). Breeding program and evaluation of semen characteristics of camels in the central rift valley of Ethiopia. An MSc Thesis Presented to the School of Graduate Studies of Alemaya University. pp. 67.

[3] Al-Otaibi and El-Demerdash (2013). Nutritive Value and Characterization Properties of Fermented Camel Milk Fortified with some Date Palm Products Chemical, Bacteriological and Sensory Properties. International Journal of Nutrition and Food Sciences. Vol. 2, No. 4, 2013, pp. 174180. doi: 10.11648/j.ijnfs.20130204.13.

[4] Amin FM (1984).The dromedary of the Sudan. The camelidall purpose animal Volume I. Proceeding of the Khartum Workshop on Camels, December, 1979. Scandinavian Institute of African Studies, Uppsala 1984. pp. 36 - 49.

[5] Borana Zone Pastoral Development Office (2010). Annual report on livestock marketing. Held in Adama, Ethiopia, June $25-30,2010$.

[6] Dejene Takele Gebissa (2014). Assessment of Dairy Cattle
Husbandry and Breeding Management Practices of Lowland and Mid-Highland Agro-Ecologies of Borana Zone. Animal and Veterinary Sciences. Vol. 2, No. 3, 2014, pp. 62-69. doi: $10.11648 /$ j.avs.20140203.12

[7] Desta S and Coppock DL (2002). Cattle population dynamics in the southern Ethiopian rangelands, $1987-97$. Journal of Range Management, 55: $439-451$.

[8] Farah KO, Nyariki DM, Ngugi RK, Noor IM and Guliye AY (2004). The Somali and the camel: Ecology, management and economics. Kamla-raj 2004 Anthropologist, 6(1):45.

[9] Getahun T and Kassa B (2002). Camel Husbandry Practices in Eastern Ethiopia: The Case of Jijiga and Shinile Zones. Nomadic Peoples 6, 158.

[10] International Livestock Center for Africa (1990).Livestock marketing. ILCA working paper 1, Livestock systems research manual volume1. International Livestock Center for Africa, December 1990, Addis Ababa, Ethiopia.pp.203-229.

[11] Megersa B, Regassa A, Kumsa B, and Abunna F (2008). Performance of camels (Camelusdromedrius) kept by pastoralists with different degree of experience in camel keeping inBorana, Southern Ethiopia. Ethiopian J.Animal Production.79: 534-548.

[12] Melaku T and Fesha G (2001). A study on the productivity and diseases of camel in Eastern Ethiopia. Journal of Tropical Animal Health and Production. 33: 265-274.

[13] Mohamed HA (1993).Traditional Practices of Camel Husbandry and Management in Somalia. The Multipurpose Camel: Interdisciplinary Studies on Pastoral Production in Somalia. Research Program on Environmental Policy and Society Department of Social and Geography, Uppsala University, Sweden.pp.123-140.

[14] Musa LMA, Peters KJ, and Ahmed MKA (2006). On farm characterization of Butana and Kenana cattle breed production systems in Sudan. Livestock Research for Rural Development. 18: 56-61.

[15] Raza HRS, Gondal KZ and Arshad I (2004).Use of Camel as Draught Animal in Pakistan. Draught Animal News (DAN) No. 40 June 2004. Center for Tropical Veterinary Medicine, University of Edinburgh. pp. 33-39.

[16] Schwartz HJ (1992). The Camel (Camelusdromedarius) in Eastern Africa. The One-Humped Camel (Camelus dromedaries) in Eastern Africa: a pictorial guide to diseases, health care, and management. Verlag Josef, Scientific Books D-6992 Weikersheim Federal Republic of Germany. pp. 1-7.

[17] Schwartz HJ and Walsh MGH (1992). The Productive Potential of the Camel. The One-Humped Camel (Camillus dromedaries) in Eastern Africa: a pictorial guide to diseases, health care, and management. Verlag Josef, Scientific Books D-6992 Weikersheim Federal Republic of Germany. pp. 30-61.

[18] Tezera G (1998). Characterization of camel husbandry practices and camel milk and meat utilization in Jijiga and Shinile zone, Somali region. An MSc. Thesis Presented to the School of Graduate Studies of Alemaya University. pp 145.

[19] Workneh N (2002). Socio-economic importance of camel in Ethiopia: An overview. A paper presented on the international workshop on Camel Research and Development: Formulating a Research Agenda for the Next Decade, Wad Medani, Sudan. pp. 9-12. 
[20] Yagil R and Etzion Z (1980). Hormonal and behavioral patterns in the male camel (Camillus dromedarius). J. Reprod. Fert.58: 61-65.

[21] Yesihak Y and Bekele T (2003). Growth pattern of one humped camel (Camillus Dromedaries). Proceeding of the $11^{\text {th }}$ Annual Conference of the Ethiopian Society of Animal
Production held in Addis Ababa, Ethiopia, August 28 - 30 , 2003. pp.157-165.

[22] Zeleke M (1998). Productivity, reproductive and health monitoring study on camel at Errer valley, Ethiopia. An MSc. Thesis Presented to the School of Graduate Studies of Alemaya University. pp. 98. 